\title{
LOSSES OF SCIENCE
}

\author{
ВТРАТИ НАУКИ
}

DOI: $10.15421 / 272031$

УДК 001(091)

\section{В. Оноприенко*, В. Савчук**}

*Институт исследований научно-технического потенщиала и истории науки им. Г. М. Доброва НАН Украины, Киев. Украина

**Днепровский национальный университет имени Олеся Гончара, Днепр, Украина

\section{ЭДУАРД КОЛЧИНСКИЙ: ПАМЯТИ ДРУГА И МОТИВАТОРА}

\author{
E-mail: valonopr@gmail.com \\ ORCID: https://orcid.org/0000-0003-0761-4075 \\ E-mail: varfolomey44@gmail.com \\ ORCID: https://orcid.org/0000-0002-6324-7567
}

Аннотация. 24 января 2020 г. в Санкт-Петербурге ушел из жизни крупнейший историк науки, биолог-эволюционист Эдуард Израилевич Колчинский. Это большая утрата для науки и для многих историков науки Украины. В течение десятилетий многие из нас дружили, общались, заряжались от него новыми идеями и замыслами. Колчинский широко известен мировому сообществу историков науки и науковедов как выдающийся исследователь и организатор науки, 20 лет руководивший Санкт-Петербургским отделением Института истории естествознания и техники Российской академии наук, основавший замечательный, высокорейтинговый журнал «Историко-биологические исследования». Доклады и публикации Колчинского всегда привлекали внимание всех, работающих в науке; проводившиеся им конференции были многолюдны и оживлённы. Он был открытым человеком, помогавшим ближним и дальним, щедро делился своим высоким интеллектуальным потенциалом, поддерживал и стимулировал молодых исследователей. Колчинский руководил крупными международными проектами,

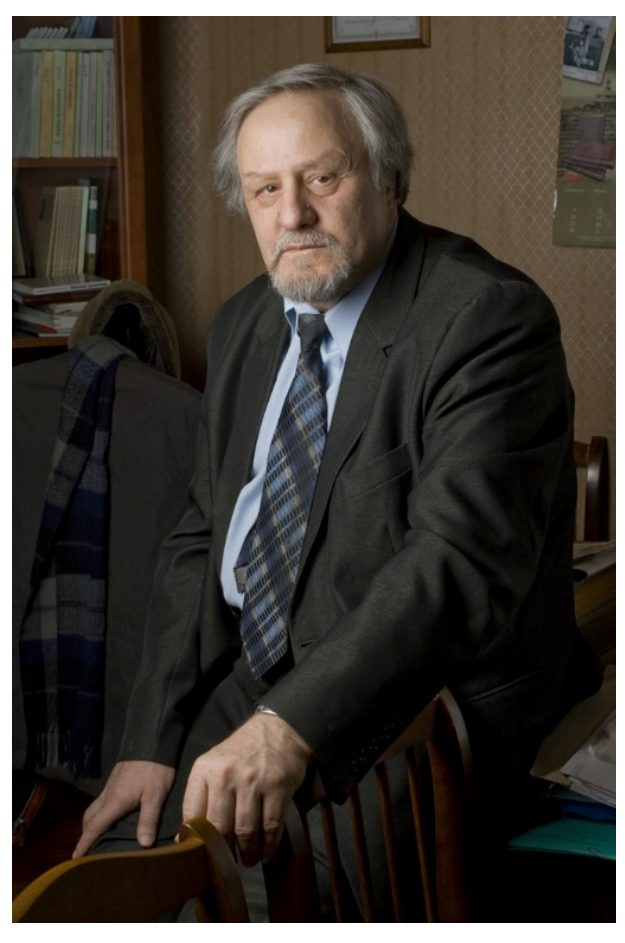
творческая энергия его была велика, он чутко улавливал новые тенденции развития науки и отзывался на них всегда оригинально и масштабно. Автор более тысячи научных и научно-популярных публикаций, нескольких десятков монографий. Он воспитал плеяду учеников - признанных учёных, последователей, единомышленников.

Ключевые слова: Эдуард Колчинский, история науки, организация науки, учение об эволюции жизни, синтез эволюционных концепций, кризисы в науке, лысенкоизм, Дарвин, Н. Вавилов. 


\section{В. Онопріснко*, В. Савчук**}

*Iнститут досліджень науково-технічного потенціалу та історії науки ім. Г. М. Доброва НАН Украӥни, Київ, Україна

**Дніпровський національний університет імені Олеся Гончара, Дніпро, Україна

\section{ЕДУАРД КОЛЧИНСЬКИЙ: ПАМ'ЯТІ ДРУГА И МОТИВАТОРА}

Анотація. 24 січня 2020 р пішов 3 життя в Санкт-Петербурзі визначний історик науки, біологеволюціоніст Едуард Ізраїлевич Колчинский. Це велика втрата для науки і для багатьох істориків науки України. Протягом десятиліть багато хто з нас дружили, спілкувалися, заряджалися від нього новими ідеями і задумами. Колчинський широко відомий світовій спільноті істориків науки і наукознавців як видатний дослідник і організатор науки, 20 років керував Санкт-Петербурзьким відділенням Інституту історії природознавства і техніки Російської академії наук, заснувавший чудовий, високорейтинговий журнал «Історико-біологічні дослідження». Доповіді та публікації Колчинського завжди привертали увагу всіх, хто працюють у науці, конференції, що проводилися ним, були багатолюдні і жваві. Він був відкритою людиною, допомагав близьким і далеким, щедро ділився своїм високим інтелектуальним потенціалом, підтримував і стимулював молодих дослідників. Колчинський керував великими міжнародними проектами, творча енергія його була велика, він чуйно вловлював нові тенденції розвитку науки і відгукувався на них завжди оригінально і масштабно. Автор понад тисячі наукових і науково-популярних публікацій, кількох десятків монографій. Він виховав плеяду учнів - визнаних вчених, послідовників, однодумців.

Ключові слова: Едуард Колчинський, історія науки, організація науки, вчення про еволюцію життя, синтез еволюційних концепцій, кризи в науці, лисенкоізм, Дарвін, М. Вавілов.

\section{Onoprienko*, V. Savchuk**}

*G. M. Dobrov Institute for Research on Scientific and Technical Potential and History of Science named after National Academy of Sciences of Ukraine, Kiev, Ukraine **Oles Honchar Dnipro National University, Dnipro, Ukraine

\section{EDUARD KOLCHINSKY: IN MEMORY OF A FRIEND AND MOTIVATOR}

Annotation. On January 24, 2020, the largest historian of science, evolutionary biologist Eduard Izrailevich Kolchinsky passed away in St. Petersburg. This is a great loss for science and for many historians of science in Ukraine. For decades, many of us have been friends, communicated, and were charged with new ideas and ideas from him. Kolchinsky is widely known to the world community of historians of science and science specialists as an outstanding researcher and organizer of science, for 20 years he headed the St. Petersburg branch of the Institute of the History of Natural Science and Technology of the Russian Academy of Sciences, and founded the remarkable, highly rated journal Historical and Biological Research. Kolchinsky's reports and publications have always attracted the attention of everyone working in science, the conferences he held were crowded and lively. He was an open person who helped near and far, generously shared his high intellectual potential, supported and stimulated young researchers. Kolchinsky was in charge of large international projects, his creative energy was great, he was sensitive to new trends in the development of science and always responded to them in an original and large-scale manner. Author of over a thousand scientific and popular science publications, several dozen monographs. He brought up a galaxy of students - recognized scientists, followers, like-minded people.

Key words: Eduard Kolchinsky, history of science, organization of science, doctrine of the evolution of life, synthesis of evolutionary concepts, crises in science, baldness, Darwin, N. Vavilov. 
Введение. Эдуард Израилевич родился 16 сентября 1944 г. в городе Карталы Челябинской области. В 1969 г. окончил философский факультет Ленинградского государственного университета им. А. А. Жданова, в 1972 г. - аспирантуру Ленинградского отделения Института истории естествознания и техники АН СССР.

Трудовую деятельность Эдуард Израилевич начал рабочим на ЮжноУральской железной дороге в 1961 году, а его научная деятельность началась с должности младшего научного сотрудника и аспиранта Института истории АН ЭССР в 1969 г. С 1973 по 1975 Э. И. Колчинский - младший научный сотрудник ЛО ИИЕТ, с 1975 по 1978 - Ботанического института АН СССР им В. Л. Комарова. С 1978 г. судьба профессора Колчинского неразрывно была связана с Санкт-Петербургским филиалом Института истории естествознания и техники им. С. И. Вавилова РАН (ЛО ИИЕТ АН СССР), которым он руководил в должности директора с 1995 по 2015 год.

Сфера его научных интересов - естественная история естествознания XVIII в.; история эволюционной биологии; научное наследие Н. И. Вавилова, В. И. Вернадского и др.

Преподавательскую деятельность Колчинский начал в 1973-1974 годах в Ленинградском сельскохозяйственном институте (сейчас - Санкт-Петербургский государственный аграрный университет); в 1976-1979 - в Ленинградском педагогическом институте им. А. И. Герцена; затем профессор до 2010 г. в Санкт-Петербургском государственном университете. В 2001-2007 гг. - приглашенный профессор в Центре истории современного образования и науки Ганноверского университета (ФРГ); в 2005, 2009. - приглашенный профессор в Университете Циньхуа (Китай).

Э. И. Колчинский - член Санкт-Петербургского общества естествоиспытателей; с 1989 года - соучредитель и член Ленинградского (Санкт-Петербургского) союза ученых; с 1991 - председатель Комиссии по методологическим аспектам теории эволюции и истории эволюционной биологии Научного совета РАН по проблемам палеобиологии и эволюции органического мира РАН; в 1998-2004 - член Научно-технического совета при губернаторе Санкт-Петербурга; с 2002 года - член Гуманитарного совета по сохранению культурного наследия СПбНЦ РАН

Родной Челябинск Колчинский никогда не забывал. Семья, соученики были его питательной средой. Школьные годи связаны с увлечённостью чтением, причём общественно-политическим, со стремлением к его систематичности (штудировал многотомную Большую Советскую Энциклопедию), что способствовало раннему интеллектуальному развитию, совмещённому с юношеским фрондёрством, отстаиванием собственного мнения, задиристостью. Одновременно была многолетняя работа на ЮжноУральской малой железной дороге, через прохождение основных профессий железнодорожника до руководства дорогой.

Материалы и методы исследования. Использован биографический метод с акцентом на реконструкцию научного вклада и варианты историографического исследования.

Целью статьи является установление основных вех творческого пути Э. И. Колчинского и главных его достижений, прежде всего в области эволюционного учения.

Результаты и обсуждения. Не поступив с первого раза в университет, Колчинский поработал на производстве, а затем уже был Ленинградский университет, философский факультет, студенческое счастье в столице. Однако, несмотря на хорошую подготовку, ощущение призвания долго не приходило. Жизненной удачей стала встреча с Кириллом Михайловичем Завадским (1910-1977), ботаником, эволюционистом, историком и философом

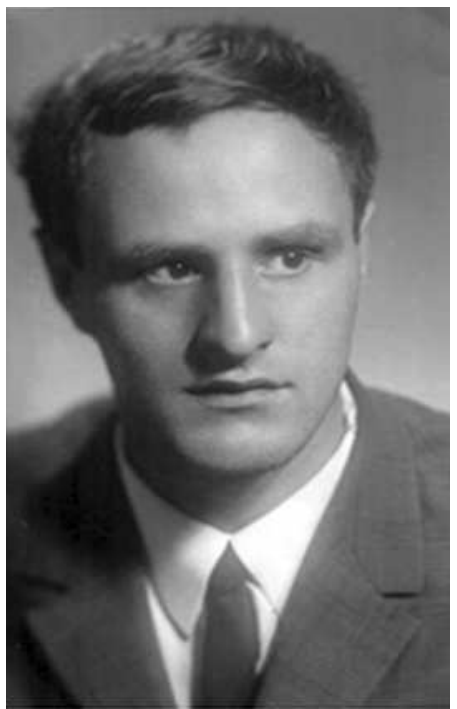

Колчинский-студент 
биологии, организатором науки. Завадский одинаково успешно работал как биологэволюционист, историк науки и специалист по философским проблемам биологии, свободно ориентируясь в сложных проблемах биологического знания. Его успеху способствовало и умение выбрать наиболее актуальные проблемы эволюционной теории, уловить только ещё зарождающиеся тенденции её будущего развития. Его личный исследовательский опыт, протекавший в аномальных условиях советской реальности и борьбы с лысонкоизмом, стал весьма значимым для его учеников. Завадский внёс существенный вклад в экспериментальное изучение движущих сил эволюции (борьбы за существование и естественного отбора) и структуры популяций растений, разработал оригинальную концепцию вида и видообразования, предложил классификацию основных уровней организации живого, исследовал критерии и закономерности прогресса, основные этапы и тенденции развития эволюционной теории от Ч. Дарвина до 1970-х гг., сформулировал программу эволюционной фитофизиологии. Обладая высоким педагогическим талантом, искренне нуждавшемся в тесной коммуникации с молодыми, Завадский в полном смысле слова, стал тем «привратником» в науку, который последовательно, настойчиво вводил в профессиональное сообщество своих учеников. Для этого он не считался ни с затратами времени, ни с колоссальным трудом по редактированию и совершенствованию текстов публикаций, ни с продвижением этих публикаций.

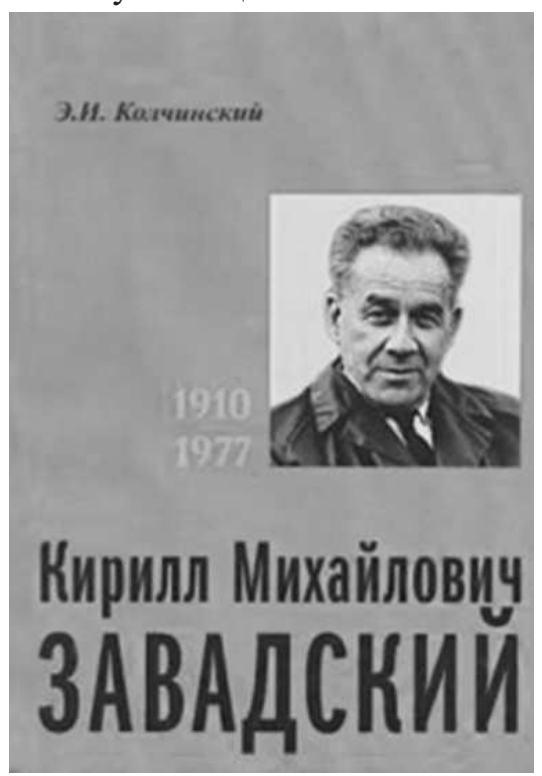

Именно Завадский оказал решающие влияние на определение поля исследовательских интересов Колчинского, побуждая всё дальше и дальше уходить от философии в сторону эволюционной теории и истории науки. В те годы Завадский фактически был лидером эволюционно-биологических исследований в нашей стране, признанным во всём мире теоретиком, историком и философом эволюционной биологии. Быть учеником Завадского было очень престижно, хотя и нелегко. Он обладал неотразимой харизмой, был очень обаятельным и прирождённым педагогом, уделявшим огромное внимание своим ученикам, постоянно беседуя с ними на различные темы, обсуждая новейшую литературу. Аспиранты должны были приходить в сектор два раза в неделю, когда там появлялся сам Завадский, к которому постоянно шли на консультацию люди со всего Советского Союза. Находясь с ним в одной комнате, аспиранты неизбежно знакомились с множеством разных проблем и могли наблюдать, как сложны поиски их решения. Важным в подготовке аспирантов, конечно, были семинары по эволюционной теории, в них участвовали крупнейшие биологи, все ведущие эволюционисты нашей страны, историки биологии, часто приезжали учёные из-за границы. Обстановка была очень демократичная. Доклады делали все - от академиков до аспирантов, каждый мог высказаться по любому вопросу и критиковать докладчика, невзирая на лица, титулы и звания. Аспиранты регулярно делали сообщения, доклады в весьма квалифицированной и требовательной аудитории. На написание первой статьи у Завадского практически у каждого уходило 1,5-2 года. Завадский по несколько раз возвращал наши рукописи, перечёркивал. Так он учил нас относиться критически к своему тексту. Он требовал глубокого знания фактического, биологического материала, высмеивал всякого рода поверхностные обобщения. Для него наука была едина для всех возрастов и стран. Где-то только через год-полтора появлялось что-то такое, что действительно можно было публиковать в серьёзных изданиях, а не в аспирантских сборниках. Как правило, это была работа, которая сразу становилась заметной в научном сообществе биологовэволюционистов. На защиту можно было выйти только после того, как появлялись 
публикации в солидных изданиях, и проходила настоящая апробация на крупных всесоюзных симпозиумах. Сами диссертации учеников Завадский, как правило, не читал, но внимательно редактировал автореферат, в итоге практически каждая защита его учеников становилась заметным событием. Поручал он редактировать труды друг друга, рецензировать статьи, рукописи монографий и диссертаций, присылаемые ему в большом количестве. Кроме того, мы помогали ему следить за мировой литературой, готовили рефераты и выписки для его работ.

Такой стиль работы был настоящей школой для молодых исследователей. Главное, что сделал Завадский для всех, кто с ним работал, это показал, чем следует руководствоваться исследователю в своей деятельности, и ввёл высокие критерии качества работы [3].

Тема дипломной работы, а затем и кандидатской диссертации Колчинского была сформулирована Завадским - «Эволюция эволюции». Она была по-настоящему трудна и проблемна, но постепенно в результате поступательного продвижения выросла в совместную с К. М. Завадским монографию «Эволюция эволюции» [8].

В книге подробно рассмотрены коллизии формирования СТЭ в разных странах, прежде всего в США, Великобритании, Германии и России. Монография имела большой успех и признание в профессиональном сообществе. По существу, эта тема стала сквозной в творчестве Колчинского, разрастаясь, ветвясь, обновляясь, обрастая переосмысленным материалом рефлексии опыта эволюционной теории в разных странах.

После смерти Завадского Колчинский принял научное руководство очень ответственной работой подготовкой коллективной монографии «Развитие эволюционной теории в СССР», задуманной ещё Завадским. Она должна была стать крупным историко-теоретическим обобщением, но работа над монографией, кроме трудностей согласования большого авторского коллектива, содержала много подводных камней, включая идеологические.

Работа над этой книгой, в которой участвовало более 20 ведущих отечественных биологовэволюционистов и историков науки, стала стимулом для формирования новых научных интересов и перспектив. В ходе работы умерли С. С. Шварц, М. М. Камшилов, которые брались написать раздел об эволюции биосферы. Найти другого автора не удалось. Пришлось писать, как нередко бывает, самому редактору-составителю. Этот проект научил Колчинского ответственности и дисциплине труда при осуществлении больших коллективных работ и умению находить альтернативы в безвыходных ситуациях. И обязательно доводить дело до результата, вопреки обстоятельствам.

Глава об эволюции биосферы получилась большая, с историко-критическим анализом реальных результатов исследований в этой области. Хотя тема эволюция биосферы была очень популярной, но Колчинскому удалось найти интегральные характеристики эволюции биосферы как специфической формы существования жизни, а также показать значение этой проблемы для эволюционной
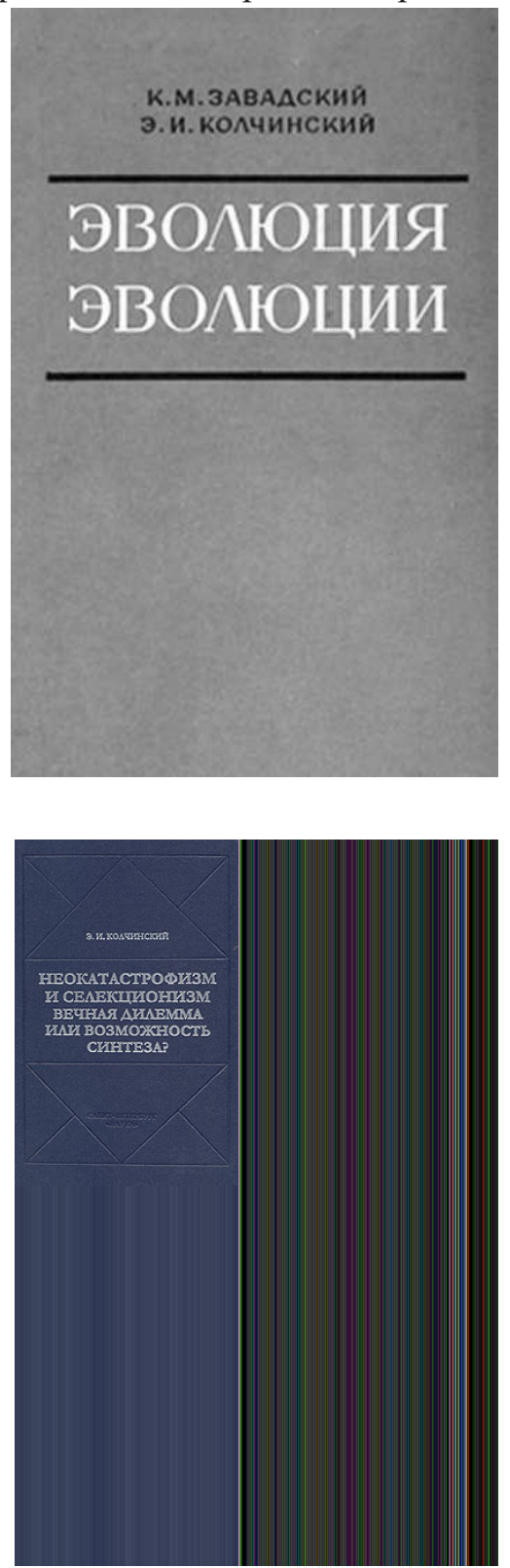
теории. Его книга «Эволюция биосферы» вышла в неудачное время для отечественной науки, в условиях крайнего её упадка и деградации. Тем не менее эта книга оказалась очень востребованной. Биосфера перестала быть абстракцией, а наполнилась конкретным содержанием благодаря выяснению аккумулятивных механизмов у живых организмов [7].

Ещё одной книгой, которую рецензенты расценили как выдающееся достижение, стала монография Э. И. Колчинского «Неокатастрофизм или селекционизм. Вечная дилемма или возможность синтеза?» [5], в которой осуществлена попытка доказать, что в современной биологии идёт создание нового синтеза, основу которого составляет объединение идей неокатастрофизма-сальтационизма и теории естественного отбора. Книга посвящена историко-критическому анализу одной из фундаментальных методологических проблем естествознания - двухвековой дискуссии между сторонниками неокатастрофистских и сальтационистских моделей эволюции. Идеи о периодической смене длительных эпох постепенных изменений геологической истории Земли и её обитателей или относительного покоя кардинальными перестройками, коренным образом преобразующими лик планеты и органический мир, зародились ещё в мифологиях Древнего мира, но научное оформление получили в начале XIX в. в теории катастроф Ж. Кювье, господствовавшей в естествознании до возникновения униформизма Ч. Лайеля и эволюционной теории Ч. Дарвина. История отношений между униформизмом и катастрофизмом, а также между градуализмом и сальтационизмом в эволюционной биологии была освещена лишь фрагментарно.

Между тем именно она позволяет понять многие отличительные черты современного эволюционизма. Кювье и его сторонники считали, что в древности имели место грандиозные вулканические извержения и быстрые, катастрофические тектонические движения, в результате которых огромные участки суши могли мгновенно оседать или вздыматься. Памятниками этих движений являются наклонные пласты и колоссальные сдвиги. Быстрые опускания земной коры приводили к внезапному распространению моря, что вызывало потопы, из которых последний был описан в Библии. Кювье считал, что в учении о катастрофах нашли примирение два факта: неизменяемость видов и неоднократная смена фауны и флоры во времени. Крупные успехи палеонтологии позвоночных, созданной Кювье и его учениками, большой материал по третичным моллюскам Парижского бассейна, собранный и описанный Ж.-Б. Ламарком, обильные ископаемые палеозоя и мезозоя, обработанные английскими геологами, свидетельствовали о том, что современная фауна значительно отличается от фауны прошлых геологических эпох. Катастрофисты допускали, что в древности происходила неоднократная гибель организмов под влиянием мощных факторов, действовавших быстро, иначе бы продолжительность жизни Земли не укладывалась в сроки, отведённые для нее Библией.

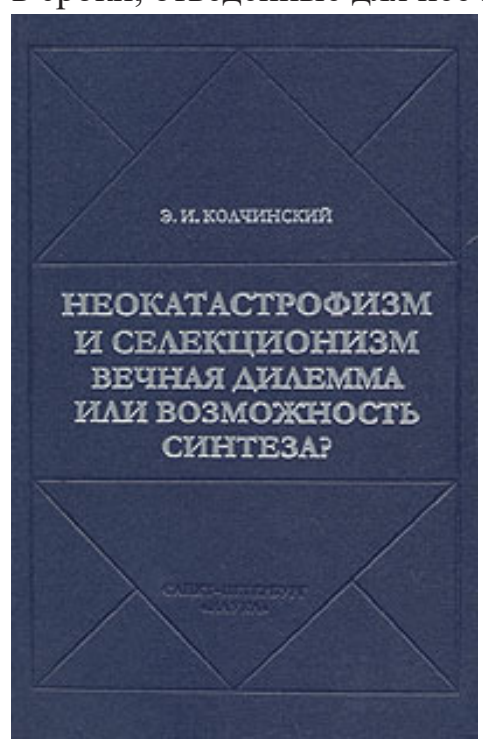

Катастрофизм, получивший широкое распространение в научном сообществе, тем не менее вызвал одновременно и реакцию неприятия со стороны ряда ведущих учёных, что постепенно привело к формированию униформистской альтернативы, наиболее чётко сформулированной Ч. Лайелем. Хотя основоположники современной исторической геологии и эволюционной биологии, уделяя основное внимание аккумуляции медленных и градуальных изменений, отодвинули на задний план сам вопрос о возможности внезапных преобразований в истории Земли и органического мира. Однако эта идея не только выжила, но и стала довольно скоро одной из основных конкурирующих с селекционизмом концепций эволюции, основанной на допущении внезапных и непредсказуемых появлений макроэволюционных новшеств, которые или сразу дают начало новым таксонам высокого ранга, или 
же вовлекаются в дальнейшие адаптивные преобразования в качестве основы будущего нового типа организации.

В книге проанализированы взгляды Дарвина относительно соотношения его теории с униформизмом, отделены его декларации от фактических положений его концепции, показаны трактовки его интерпретаторов, начиная с Т. Гексли, и особенно тщательно исследована «дарвиниана» последних десятилетий. В книге усилен и акцентирован вывод, сделанный К. М. Завадским и Э. И. Колчинским ещё в 1977 г., о том, что теорию Дарвина следует оценивать, как важный шаг на пути синтеза униформизма и катастрофизма, как по сути неоуниформистскую концепцию. Показано, как антиэволюционный катастрофизм трансформировался в эволюционную модель, давшую начало широкому спектру концепций и гипотез, и как одновременно шла трансформация различных форм селекционизма, приведя в 1930-е гг. к формированию синтетической теории эволюции (СТЭ) с ее стремлением ассимилировать все достижения недарвиновских концепций эволюции, включая сальтационизм и неокатастрофизм.

Это, в свою очередь, способствовало развитию и автогенетического, и эктогенетического неокатастрофизма. Значительная часть книги посвящена детальному рассмотрению СТЭ в её соотношении с неокатастрофизмом. Вскрыты предпосылки и причины необходимости синтеза в эволюционном учении, в котором в связи с созданием мутационной концепции Г. де Фриза был нарушен баланс между сторонниками градуализма и сальтационизма в пользу последнего. В условиях далеко продвинувшейся дифференциации биологии, возникновение таких дисциплин как феногенетика, биология развития, цитогенетика, этология синтез эволюционных идей, разрабатывавшихся генетиками, систематиками и палеонтологами, произошло в период между 1937 и 1950 гг. Многие учёные из разных отраслей биологии к этому времени признали правильность предположения о ведущей аккумулирующей роли отбора в механизме эволюции. Новую аргументацию для этого предоставила популяционная концепция. В результате наметившегося консенсуса современный дарвинизм стали называть синтетической теорией эволюции (СТЭ). Богатством содержания и логикой аргументации книга имеет общекультурную ценность. Её можно порекомендовать как образец историко-научного исследования не только многим историкам науки, в том числе работающим в других областях, но и биологам, геологам, палеонтологам, философам, не испытывающим профессионального интереса к истории науки, но уверен, что после её прочтения интерес проявится.

Для многих, оставшихся в науке после полного её облома в начале 1990-х годов, было очевидно, что необходимо как-то менять стереотипы деятельности, которые владели нами в течение десятилетий. Немалая часть учёных в принципе не могла представить себя вне исследовательской работы, но и существование в условиях, когда временами вообще не платили за работу, тоже закрывало всякую перспективу. Э. И. Колчинский испытал и испробовал в эти трудные годы то, что делали многие, правда, он был гораздо активнее многих: первые соросовские гранты, поездки за рубеж за счёт приглашающей стороны, преподавательская деятельность, конкурсная борьба за первые гранты российских фондов содействия науки и т. д. Было очевидно, что, даже сохраняя тематику исследований, её следует существенно обновлять и модернизировать.

В 1995 г. Э. И. Колчинский избран директором СПбФилиала ИИЕТ РАН, его инициатива и ответственность за судьбу коллектива резко возросли. Важной долговременной новацией стало обращение к социальной истории науки. В эти годы появились в разных регионах бывшего Союза много публикаций, якобы принадлежащих к этому жанру, в трагической судьбе учёных винили «великий перелом», партийногосударственный аппарат и его приспешников среди учёных. Колчинский понимал, что профессиональное сообщество всегда неоднородно, в нём всегда идёт борьба за финансирование исследований и взаимодействие с властью, какой бы она ни была. Всегда есть, и не мало, видных учёных, использующих преимущества государственного управления наукой для борьбы со своими конкурентами. Эта мысль вошла в арсенал историко-критического подхода к оценке истории организации науки. Серия публикаций 
по социальной истории науки, поставленных на прочную методологическую основу, стали важнейшим направлением петербургских историков науки в 1990-2000 годы. Серия публикаций по социальной истории науки, поставленных на прочную методологическую основу, стали важнейшим направлением петербургских историков науки в 1990-2000 годы. Многие из них готовились по международным проектам и быстро завоевали международное признание.

В коллективной монографии «Наука и кризисы» [9] рассматривалось поведение научных сообществ и властей разных стран в периоды кризисов, начиная от английской революции XVII века до «культурной революции» в Китае. Во время работы над этой книгой Колчинского заинтересовала также задача сравнительного анализа развития биологии в России и в Германии, особенно в период господства тоталитарных режимов. В течение ряда лет он неоднократно бывал в Германии и собрал обширный материал о немецких биологах в национал-социалистической Германии, что позволило показать, что не столько идеология, сколько тоталитаризм заставлял учёных разных стран вести себя сходным образом, чтобы обеспечить государственную поддержку своих исследований, а иногда и убрать конкурентов.

В Санкт-Петербургском филиале ИИЕТ РАН Колчинский фактически, будучи философом по образованию, превратился в квалифицированного и авторитетного биолога. Его учителями в биологии были биолог-эволюционист К. М. Завадский, выдающийся протозоолог, член-корреспондент РАН, бывший ректор Ленинградского университета Ю. И. Полянский и последовательный борец с лысонкоизмом с довоенным стажем Д. В. Лебедев. Особенность Колчинского в том, что он постоянно находился в сетевом сотрудничестве и кооперации со многими биологами и историками биологии не только в России, но и во многих странах мира. Вообще его путь как философа естествознания неординарен: как правило, специалисты в этой области рекрутировались в СССР из конкретных областей естествознания и техники (и эта традиция сохранилась до сих пор). Он же шёл в обратном направлении, поэтому его девиз: историк науки должен писать, прежде всего, для специалистов той или иной отрасли знания, а социальная история науки без понимания и анализа конкретных проблем самой науки схоластична и неинтересна.

За время директорства Колчинского в СПб-Филиале ИИЕТ РАН (а это два десятка лет) кардинально изменилось само исследовательское поле учреждения, причём он сыграл в этом процессе самую активную роль. Отмена цензуры, открытие архивов, свобода коммуникаций с зарубежными коллегами позволили коренным

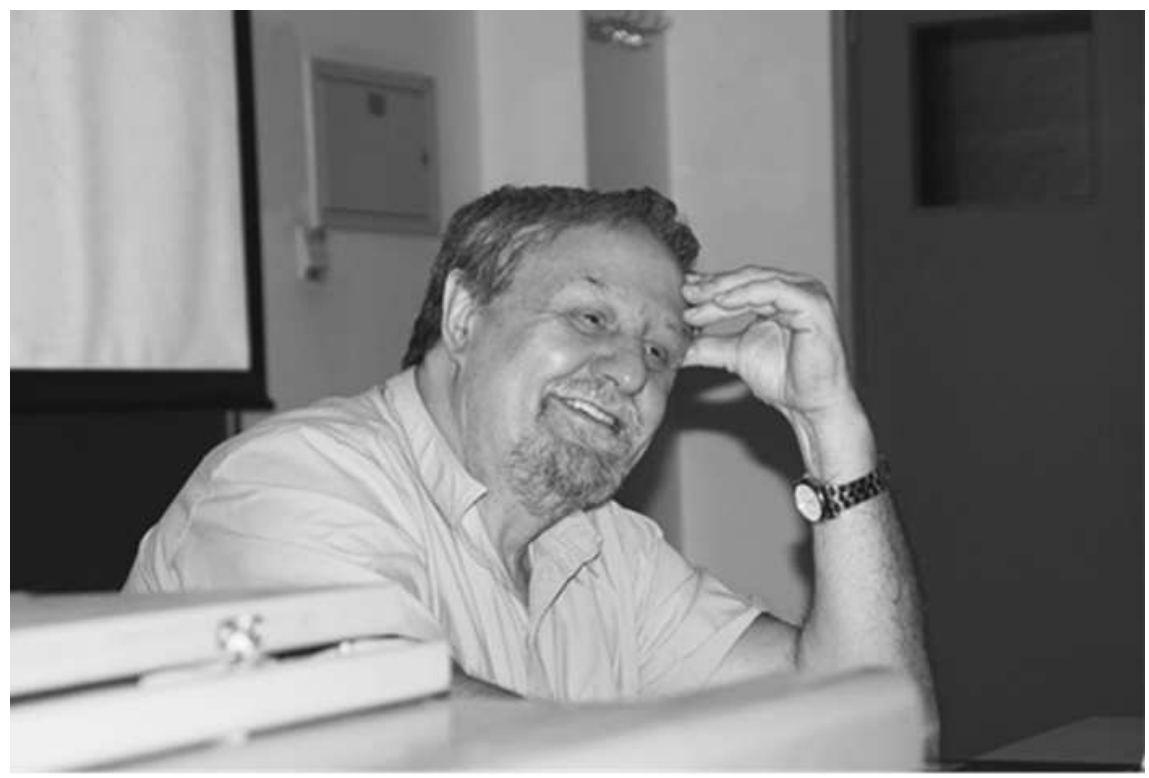

Э. И. Колчинский - директор СПбФилиала ИИЕТ РАН 
образом расширить спектр исследований [10]. Кроме того, иногда импульс к новым исследованиям исходил от зарубежных коллег, приглашавших принять участие в том или ином проекте. Учитывать приходится и проходимость тематики проекта при конкурсах в РФФИ и РГНФ. Как директору ему приходилось искать компромисс между стабильностью и изменчивостью, фундаментальностью и конъюнктурностью, и с сохранением традиционных направлений всячески стимулировать зарождение новых, поощрять внедрение новых методов исследования, поиск новой методологии и т. д. Он исходил из того, что в науке каждый должен заниматься любимым делом, но при этом не забывать, кто будет финансово обеспечивать это занятие и соответствует ли оно основным направлениям научной деятельности ИИЕТ. В идеале молодёжь должна сама выбирать исследовательские темы, а задача руководителя в их поддержке, а также в выдвижение крупных коллективных проектов и в обеспечении их руководства. Ряд таких проектов удалось предложить коллективу и их реализация, например, четыре тома «Летописи РАН», «Наука за «железным занавесом», «Наука, техника и общество Германии и России во время Первой мировой войне» и др., способствовала повышению авторитета учреждения. При этом каждый исследователь всегда должен стремиться быть частью мирового научного сообщества, активно сотрудничать с зарубежными коллегами.

За время директорства Колчинского изменился сам статус СПб-Филиала ИИЕТ в питерском научном ландшафте - история и социология науки выдвинулись в приоритеты. Крупнейшие проекты - 4 тома «Летописи РАН», 10 томов второго Полного собрания сочинений М. В Ломоносова, Биология в Санкт-Петербурге. Энциклопедический словарь, Немцы в России: встречи на перекрестке культур, Создатели современного эволюционного синтеза, В. И. Вернадский и Комиссия по истории знаний, Комиссии Академии наук в XVIII-XX веках, Российские экспедиции в Центральную Азию, Эволюционный синтез: границы, перспективы, альтернативы, издание двух авторитетных журналов «Историко-биологические исследования» и «Социология науки технологий» - реально привлекли внимание руководства СПб научного центра во главе с академиком Ж. И. Алфёровым и усилили консолидизирующую роль Филиала ИИЕТ в области истории, социологии и философии науки.

Выводы. Чтобы представить масштаб деятельности СПб-Филиала ИИЕТ, в составе которого 25-28 человек, приведём сделанную нами выборку только книжных изданий (вынужденно сокращённую) за 2011-2015 годы.

Биология в Санкт-Петербурге. 1703-2008. Энциклопедический словарь / отв. ред. Э. И. Колчинский; ред.-сост. Э. И. Колчинский, А. А. Федотова. СПб.: Нестор-История, 2011. 566 с. Конашев М. Б. Становление эволюционной теории Ф. Г. Добржанского. СПб.: Нестор-История, 2011. 180 с. Ломоносов М. В. Полное собрание сочинений. 2-е изд., испр. и доп. В 10 томах. / гл. ред. Ю. С. Осипов; науч. ред.: Ж. И. Алферов, Э. П. Карпеев, Д. А. Варшалович, И. С. Дмитриев, Э. И. Колчинский, В. Г. Смирнов, Э. А. Тропп, В. М. Лоскутов, П. В. Ильин, М. В. Семиколенных, Г. И. Смагина, В. С. Соболев, И. Б. Соколова, Н. Г. Сухова, Д. А. Щеглов. СПб.: Наука, 2011-2012. Немцы в России: встречи на перекрестке культур / отв. ред. Д. Дитмар, Г. Смагина. СПб.; Росток, 2011. 542 с. Галл Я. М. Георгий Францевич Гаузе (1910-1986). Научная биография. СПб.: Нестор-История, 2012. 215 с. Жмудь Л. Я. Пифагор и ранние пифагорейцы. Москва: Ун-т Дмитрия Пожарского, 2012. 445 с. Конашев М. Б. Эволюционисты и религия. СПб.: Нестор-История, 2012. 200 с. Монгольско-российское научное сотрудничество: от Учёного комитета до Академии наук / ред.-сост. С. Чулуун и Т. И. Юсупова. Улаан-баатар, 2012. 182 с. Немцы в России. 2-е изд. / отв. ред. Г. И. Смагина. СПб.: Лики России, 2012. 255 с. Смагина Г. И., Анненкова Э. А. Просвещённый благотворитель принц П. Г. Ольденбургский. СПб.: Лики России. 2012. 183 с. Соболев В. С. «Нести священное бремя прошедшего...»: Российская Академия наук и национальное культурное наследие. 1880-1930. СПб.: Нестор-История, 2012. 378 с. Создатели современного эволюционного синтеза / Ред.-сост. Э. И. Колчинский. Ред. А. В. Полевой и С. И. Зенкевич. СПб.: Нестор-История. 2012. 
996 с. В. И. Вернадский и Комиссия по истории знаний. К 150-летию со дня рождения В. И. Вернадского / Отв. ред. Ю. М. Батурин. Ред.-сост. В. М. Орел и Г. И. Смагина. М., СПб.: Росток, 2013. 605 с. Георгиевский А. Б. Эволюционное творчество Л. С. Берга. СПб.: Нестор-История, 2013. 108 с. Колчинский Э. И. Историко-научное сообщество в Ленинграде-Санкт-Петербурге в 1950-2010-е гг.: люди, традиции, свершения (К 60-летию Санкт-Петербургского филиала Института истории естествознания и техники им. С. И. Вавилова РАН) / ред. С. И. Зенкевич и В. Г. Смирнов. СПб.: Нестористория, 2013. 447 с. Колчинский Э. И. Кирилл Михайлович Завадский. 1910-1977. Серия «Научно-биографическая литература» РАН. СПб.: Нестор-История, 2013. 319 с. Комиссии Академии наук в XVIII-XX веках: Исторические очерки / Отв. ред. Ю. М. Батурин; ред.-сост. Г. И. Смагина, Э. А. Тропп. СПб.: Нестор-История, 2013. 732 с. Российские экспедиции в Центральную Азию: Организация, полевые исследования, коллекции. 1870-1920-е гг. / Под ред. А. И. Андреева, Т. Ю. Гнатюк и М. Н. Кожевниковой. СПб.: Нестор-история, 2013. 331 с. Эволюционный синтез: границы, перспективы, альтернативы / Отв. ред.-сост. Г. Левит, Э. И. Колчинский, У. Хоссфельд, У. Кучера и Л. Олсон. СПб.: Роза ветров, 2013. 274 с. Ли Чэнчжи. Развитие китайских космических технологий / Под ред. Бао Оу, Хан Ихуа, Ю. М. Батурина, Б. Б. Дьякова, Б. И. Иванова и Д. Н. Савельевой. СПб.: Нестор-История, 2013. - 236 с. Перевод с китайского А. Кузиной. Ащзеулова Н. А., Душина С. А. Мобильная наука в глобальном мире / Отв.ред. В. М. Ломовицкая. СПб.: Нестор-История, 2014. 224 с. Смирнов В. Г. Академик М. А. Рыкачев и развитие геофизики в России. СПб.: НесторИстория, 2014. 600 с. Лоскутова М. В., Федотова А. А. Становление прикладных биологических исследований в России: взаимодействие науки и практики в XIX-начале XX вв. Исторические очерки / отв. ред. Э. И. Колчинский. СПб.: Нестор-История, 2014. - 220 с. Федотова А. А., Гончаров Н. П. Бюро по прикладной ботанике в годы Первой мировой войны: сборник документов / Подготовка к печати, вступительная статья и комментарии А. А. Федотовой, Н. П. Гончарова; отв. ред. Э. И. Колчинский. СПб.: Нестор-История, 2014. 268 с. Максимум возможного. Переписка Ф. Г. Добржанского с отечественными биологами (1920-1970 гг.). Часть 1: Переписка Ф. Г. Добржанского с отечественными биологами: 1920-1930 гг. / М. Б. Конашев (ред.-сост.). СПб.: НесторИстория, 2014. 796 с. Колчинский Э. И. Единство эволюционной теории в разделённом мире XX века. СПб.: Нестор-История, 2014. 824 с. Соболев В. С. Во главе первого учёного общества империи: нормативно-правовые основы деятельности президентов РАН. 1725-1917 гг. СПб.: Нестор-История, 2015. 184 с. 132 Немцы в России. Немецкий мир Санкт-Петербурга: Сб. статей / Отв. ред. Д. Дальманн, Г. И. Смагина. СПб.: ООО «Издательство «Росток», 2015. 688 с.К такому списку нечего добавить: не только их

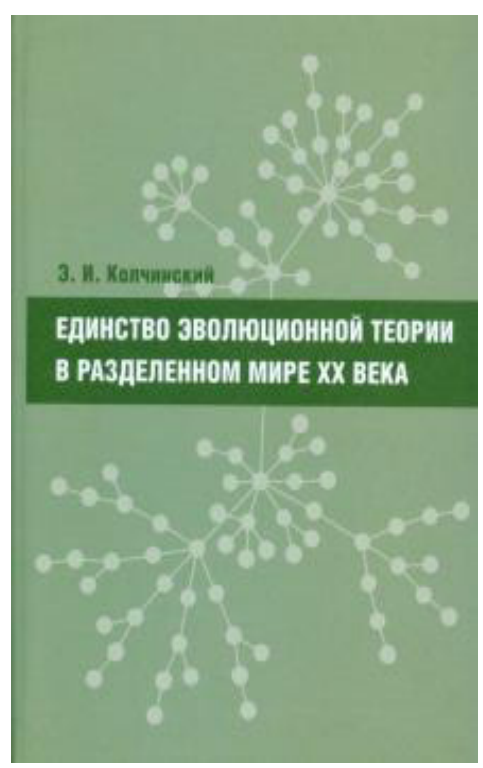

количество и объемы, не только их количество и объемы, но и особенно разнообразие жанров говорят сами за себя, и в Академии наук нельзя найти какого-либо аналога даже среди наиболее первоклассных институтов.

Э. И. Колчинский оставил пост директора Филиала по болезни, которая неуклонно наступала, но также и потому, чтобы сосредоточиться на том, что ещё хотелось сделать. Прежде всего следует сказать о колоссальной его монографии «Единство эволюционной теории в разделённом мире $\mathrm{XX}$ века». Необходимость такого обобщения назрела в мировом научном сообществе, но никто из ведущих эволюционистов не мог на это отважиться. Книга стала итогом непрерывных дискуссий о путях развития эволюционного синтеза. Для Колчинского она стала «книгой жизни», вышла сразу двумя изданиями.

Её дополняет в личностном плане книга воспоминаний с очень характерным для него 
скептическим подзаголовком «Так вспоминается, или ещё одно лжесвидетельство» (2014) [6], получившая весьма одобрительные отзывы. Материал воспоминаний - важнейший источник для реконструкции повседневных форм коммуникации, в том числе в сфере науки. Учёт повседневных форм жизни обогащает аналитические подходы к характеристикам homo scientifi cus. Повседневность нормирует, заземляет многие официальные идеологемы, афишируемые нормы и лозунги. Такая черта характерна и для автора воспоминаний, всегда стремившегося снять официозный пафос и фальшь оболванивания людей.

Без Колчинского нельзя представить грандиозный проект ИИЕТа последних лет, в трёх томах, осуществлённый командой из 30 историков науки и техники по новой методологии под руководством члена-корреспондента РАН Ю. А. Батурина «Вихревая динамика истории науки и техники в России / СССР» [1]. Последняя его книга «Мобилизация и реорганизация российской науки и образования в годы Первой мировой войны» (СПб.: Нестор-История, 2019. 672 с.) [4]. В ней трансформация научных и образовательных учреждений России под влиянием Первой мировой войны анализируется как процесс создания мобилизационной модели организации науки и связанной с ней перестройки системы взаимоотношений учёных с властью и обществом. Как Первая мировая война предопределила дальнейшее развитие России, так и советская модель организации науки в значительной степени формировалась в 1914-1917 гг. Этот вывод носит мощный методологический смысл, ведь десятилетиями этот сдвиг переносился вглубь 1920-х - 30-х годов. Мировое признание выдающихся научных достижений Э. И. Колчинского - членство во многих крупных научных обществах - член Deutsche Gesellschaft für Geschichte und Theorie der Biologie (1994); член History
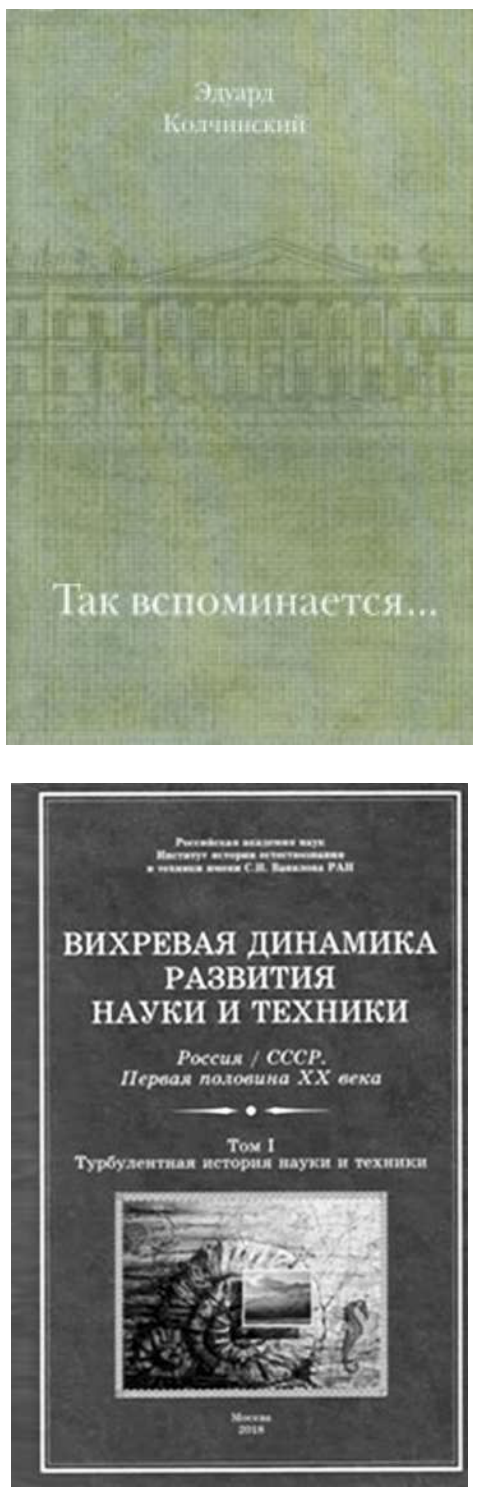
of Science Society (с 1997); член (2007), почетный член (2012) die Internationale Georg-Wilhelm-Steller-Gesellschaft; почетный член Сербского общества биологов (2009); European Society for the History of Science (с 2010); член The Linnean Society of London (c 2010 г.); почетный член Сербского общества истории науки (2011); членкорреспондент Международной Академии истории науки (L'Académie internationale d'histoire des sciences) (2012), действительный член (2019); член The British Society for the History of Science (BSHS) (2013).

\section{REFERENCES}

1. Vikhrevaya dinamika razvitiya nauki i tekhniki. Rossiya/SSSR [Vortex dynamics of the development of science and technology. Russia / USSR]. (2018). KhKh vek: v trekh tomakh. Tom I: Turbulentnaya istoriya nauki i tekhniki [Turbulent history of science and technology] / Otv. red. chl.-korr. RAN Yu. M. Baturin; In-t istorii estestvoznaniya i tekhniki im. S. I. Vavilova. M.: IIET RAN; Saratov: Amirit, 658 s.; Tom 2: Ekstremalnyi rezhim razvitiya nauki i tekhniki [Extreme mode of development of science and technology]. 2018, 721 s.; Tom 3: Samoorganizatsiya, turbulentnyi perekhod $i$ dissipatsiya [Self-organization, turbulent transition and dissipation] / Otv. red. chl.-korr. RAN Yu. M. Baturin. M.: IIET RAN; Saratov: Amirit, 2019, 836 s. 
2. Kolchinskii E. I. (2014). Edinstvo evolyutsionnoi teorii v razdelennom mire XX veka [The unity of evolutionary theory in the divided world of the twentieth century]. SPb.: Nestor-Istoriya, $824 \mathrm{~s}$

3. Kolchinskii E. I. (2013). Kirill Mikhailovich Zavadskii. 1910-1977 [Kirill Mikhailovich Zavadsky 1910-1977]. Seriya «Nauchno-biograficheskaya literatura» RAN. SPb.: Nestor-Istoriya, $319 \mathrm{~s}$.

4. Kolchinskii E. I. i dr. (2019). Mobilizatsiya i reorganizatsiya rossiiskoi nauki i obrazovaniya v gody Pervoi mirovoi voiny [Mobilization and reorganization of Russian science and education during the First World War]. SPb.: Nestor-Istoriya, $672 \mathrm{~s}$.

5. Kolchinskii E. I. (2002). Neokatastrofizm i selektsionizm. Vechnaya problema ili vozmozhnost sinteza? (Istoriko-kriticheskie ocherki) [Neocatastrophism and selectionism: an eternal problem or a possibility of synthesis? (Historical and critical essays)]. SPb.: Nauka, $554 \mathrm{~s}$.

6. Kolchinskii Eduard (2014) Tak vspominaetsya, ili eshche odno lzhesvidetelstvo [So it comes to mind, or another perjury]. SPb.: Nestor-Istoriya, $572 \mathrm{~s}$.

7. Kolchinskii E. I. (1990). Evolyutsiya biosfery. Istoriko-kriticheskie ocherki issledovanii v SSSR [Evolution of the biosphere. Historical and critical studies of research in the USSR]. L.: Nauka.

8. Zavadskii K. M., Kolchinskii E. I. (1977). Evolyutsiya evolyutsii Istoriko-kriticheskie ocherki problem [Evolution of evolution. Historical and critical sketches of the problem]. L.: Nauka, $236 \mathrm{~s}$.

9. Nauka i krizisy (2003) Istoriko-sravnitelnye ocherki [History and crises. Historical and comparative essays]. Red.-sost. E. I. Kolchinskii. SPb.: Dmitrii Bulavin, 1039 s.

10. Onoprienko V.I. (2011). Intervyu s E. I. Kolchinskim «Neupushchennye vozmozhnosti» [Interview with E. I. Kolchinsky: «Opportunities not missed»]. V: Onoprienko V. Nauka kak prizvanie. Kniga intervyu [Science as a vocation. Interview book]. Kiev: Inform.-analit. agentstvo».

11. Razvitie evolyutsionnoi teorii v SSSR [Development of evolutionary theory in the USSR]. (1983). / Otv. red. Yu. I. Polyanskii, red.-sost. E. I. Kolchinskii. L.: Nauka, 613 c.

Received 15.08.2020

Accepted 15.09. 2020 